\title{
Design and Analysis of Rectangular and U Slotted Microstrip Patch using Optimization Program in Java for UHF Applications
}

\author{
Aruna Rani \\ Assistant Professor \\ Dept. of Computer Sc. And Engg. \\ G.B. Pant Engineering College, Pauri \\ Uttarakhand, India
}

\author{
R.K. Dawre \\ Executive Engineer \\ Power Transmission Corporation \\ of Uttarakhand Limited, \\ Uttarakhand India
}

\begin{abstract}
This paper presents Microstrip antenna in the application for a military band short range radio communication system ultra high frequency(UHF), at a frequency range of $1 \mathrm{Ghz}-1.5 \mathrm{Ghz}$. Currently, most military aviation platforms are equipped with UHF communication system for their operational requirements, a design studies in the development for a lightweight, low volume, low profile. Hence, in this paper, bandwidth enhancement techniques such as use of various substrate with low relative dielectric constant $(\mathcal{E} r)$, size of antenna as well as $U$ slotted patch antenna with coaxial probe feed technique are discussed and explained using optimization program in java and the genetic algorithm is developed.
\end{abstract}

\section{General Terms}

Microstrip antenna, communication, dielectric constant, frequency, bandwidth, java program, algorithm.

\section{Keywords}

Optimization program, genetic algorithm, UHF, U slot.

\section{INTRODUCTION}

Because of the booming demand in wireless communication system and UHF applications, microstrip patch antennas have attracted much interest due to their low profile, light weight, ease of fabrication and compatibility with printed circuits. However, they also have some drawbacks, such as narrow bandwidth, low gain spurious feed radiation limited power handling capacity . To overcome their inherent limitation of narrow impedance, bandwidth and low gain, many techniques have been proposed and investigated, e.g., for probe fed stacked antenna, microstrip patch antennas on electrically thick substrate, slotted patch antenna and stacked shorted patches using optimization program in java and the genetic algorithm. When we change the shape of a microstrip antenna and it is covered with a dielectric layer, its properties like resonance frequency, gain are changed which may seriously degrade or upgrade the system performance. Therefore, in order to introduce appropriate correctness in the design of the antenna, it is important to determine the effect of dielectric layer and shapes on these antenna parameters. This paper describes the use of Genetic Algorithm shown in figure 3, and optimization program to analyze the gain of a rectangular microstrip antenna. Genetic Algorithm is a class of search techniques that use the mechanisms of natural selection and genetics to conduct a global search of the solution and this method can handle the permittivity and the shape (U) slot of the rectangular microstrip antenna. The Genetic Algorithm program, for the optimization of microstrip antenna using this program, The bandwidth is analyzed by changing the substrate material at the frequency range $1 \mathrm{GHz}$ to $1.5 \mathrm{GHz}$ and introducing the slots $\mathrm{U}$. The results are simulated with java optimization program . Stack configuration with 2 patches, driven and parasitic, and the use of the various substrate loading technique increases the bandwidth of the antenna ranging from $23 \%-32 \%$. If we increase the height $(40 \mathrm{~mm})$ of the patch for $\varepsilon r=3$ (mylar) the bandwidth can be increased up to $61 \%$.

\section{ANTENNA CONFIGURATION}

The configuration of the proposed patch antenna parasitic and driven is illustrated in Figure 1 and Figure 3 respectively. For the U-slotted patch, the slots are embedded to the rectangular patch.where, $\mathrm{L}$ and $\mathrm{W}$ are the length and width of the patch. Er is the dielectric constant, $\Delta \mathrm{L}$ is the length due to the fringing field .The fringing fields along the width can be model as radiating slots and electrically the patch of the microstrip antenna looks greater than its physical dimensions. The dimensions of the patch along its length have now been extended on each end by a distance $\Delta L$, which is given empirically by Hammerstad [1] as:

$(\varepsilon r e f f+0.3)(\mathrm{W} / \mathrm{h}+0.264)$

$\Delta \mathrm{L}=0.412 \mathrm{~h}$

$($ reff -0.258$)(\mathrm{W} / \mathrm{h}+0.8)$

The effective length of the patch Leff now becomes:

$$
\text { Leff }=\mathrm{L}+2 \Delta \mathrm{L}
$$

Or

For a given resonant frequency fo, The effective length is given as:

$$
\text { Leff }=\frac{c}{2 \text { fo } \sqrt{\text { greff }}}
$$


For a rectangular Microstrip patch antenna, the resonance frequency for any TMmn mode is given by James and Hall [2] as:

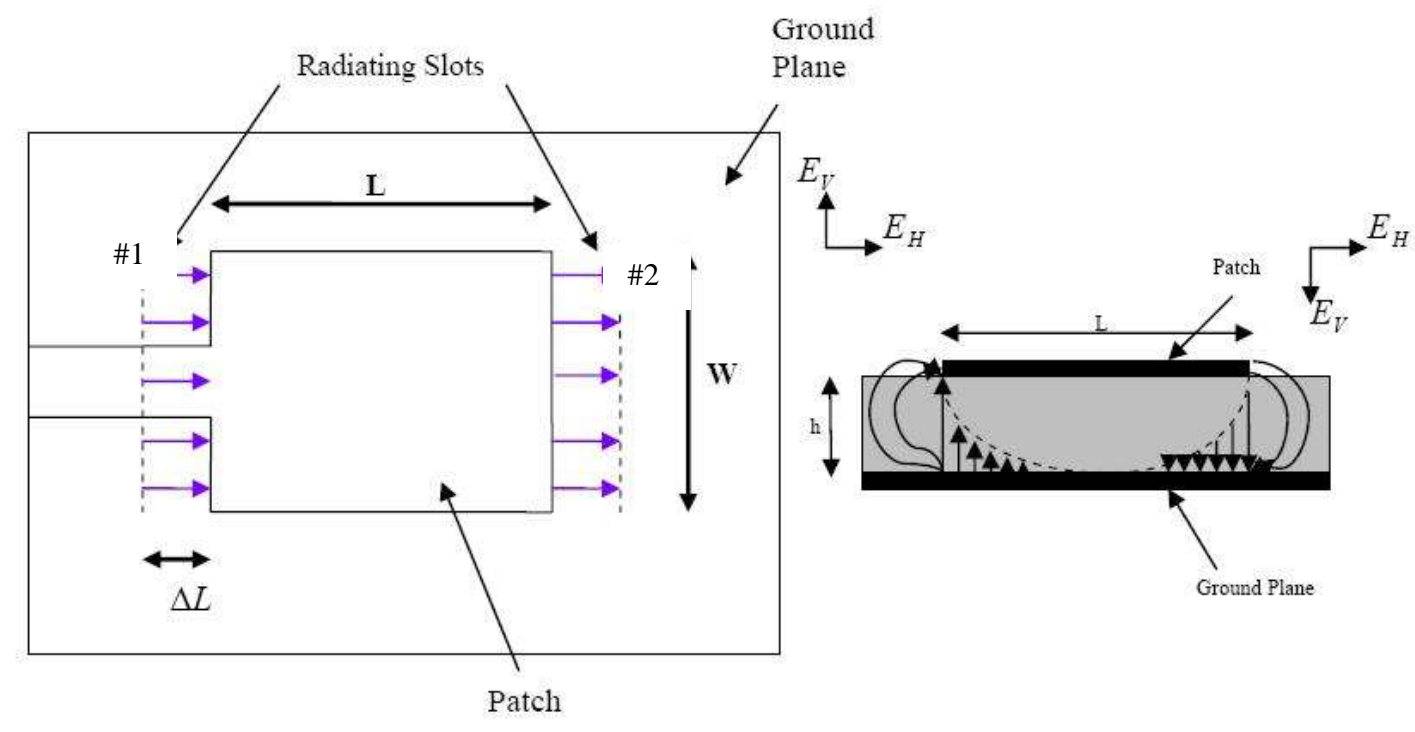

Figure-1 Rectangular Microstrip Antenna

$$
\text { Ereff }=\frac{\varepsilon r+1}{2}+\frac{\varepsilon r-1}{2}\left[1+12 \frac{h}{W}\right]^{1 / 2}
$$

The width $\mathrm{W}$ is given by Bahl and Bhartia [3] as:

$$
W=\frac{c}{2 \text { fo } \sqrt{\frac{(\varepsilon r+1)}{2}}}
$$

The Cunductance $\mathrm{G}$ and susceptance B as shown in Figure 2. The slots are labeled as \#1 and \#2. The equivalent admittance of slot $\# 1$, based on an finitely wide, uniform slot is given by [1] $\mathrm{Y} 1=\mathrm{G} 1+\mathrm{jB} 1$. Since slot \#2 is identical to slot \#1

Hence $\mathrm{Y} 2=\mathrm{Y} 1, \mathrm{~B} 2=\mathrm{B} 1, \mathrm{G} 2=\mathrm{G} 1$.

Total impedance $\mathrm{Zin}=(1 / \mathrm{Yin})=\mathrm{Rin}=(1 / 2 \mathrm{G} 1)$

$\% \mathrm{BW}=(($ fhigh - flow $) /$ fo $) 100$

where fr is the resonant frequency, while fhigh and flow are the frequencies between the magnitude of the reflection coefficient of the antenna is less than or equal to $1 / 3$. In general, bandwidth is proportional to the volume, which for a microstrip antenna at a constant resonant frequency can be express as

$\mathrm{BW} \sim$ volume $=$ area $\mathrm{x}$ height $=$ length $\mathrm{x}$ width $\mathrm{x}$ height

An empirical formula by Jackson and Alexopolus for the bandwidth $(\mathrm{VSWR}<2)$ is

$\left.\mathrm{BW}=3.77[\varepsilon \mathrm{r}-1 / \varepsilon \mathrm{r} 2)(\mathrm{W} / \mathrm{L})\left(\mathrm{h} / \lambda_{\mathrm{o}}\right)\right]$

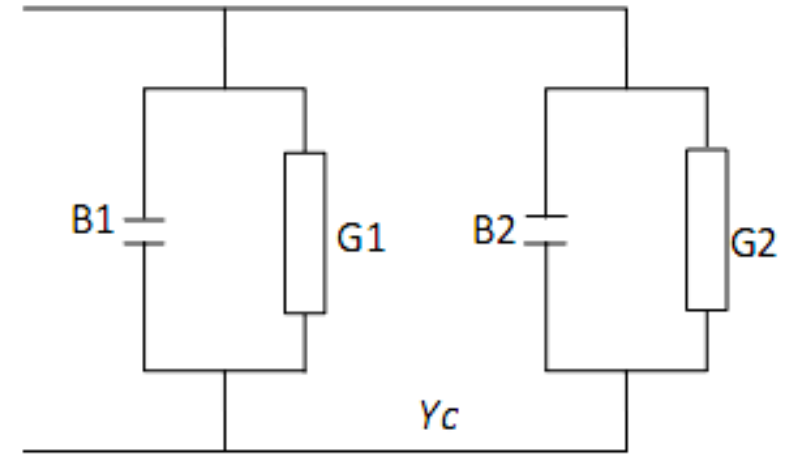

Figure-2 Transmission model of rectangular patch

\section{DESIGN AND THEORITICAL CONCIDERATION OF U SLOT}

This design procedure is a set of simple design steps for the rectangular U-slot mircostrip patch antenna on microwave substrates . Determine centre frequency, fo Set center frequency as fo and the lower and upper frequency bounds of the bandwidth as flow and fhigh, respectively.

a. Center frequency, fo $=1.25 \mathrm{GHz}$

b. Lower bound frequency, flow $=1 \mathrm{GHz}$

c. Upper bound frequency, fhigh $=1.5 \mathrm{GHz}$

Slot thickness $\mathrm{E}$ and $\mathrm{F}$ is defined as:

$$
\mathrm{E}=\mathrm{F}=\lambda / 60
$$


Slot width D:

$$
\mathrm{D}=\frac{\mathrm{c}}{2 \text { flow } \sqrt{\text { Ereff }}}-2(\mathrm{~L}+2 \Delta \mathrm{L}-\mathrm{E})
$$

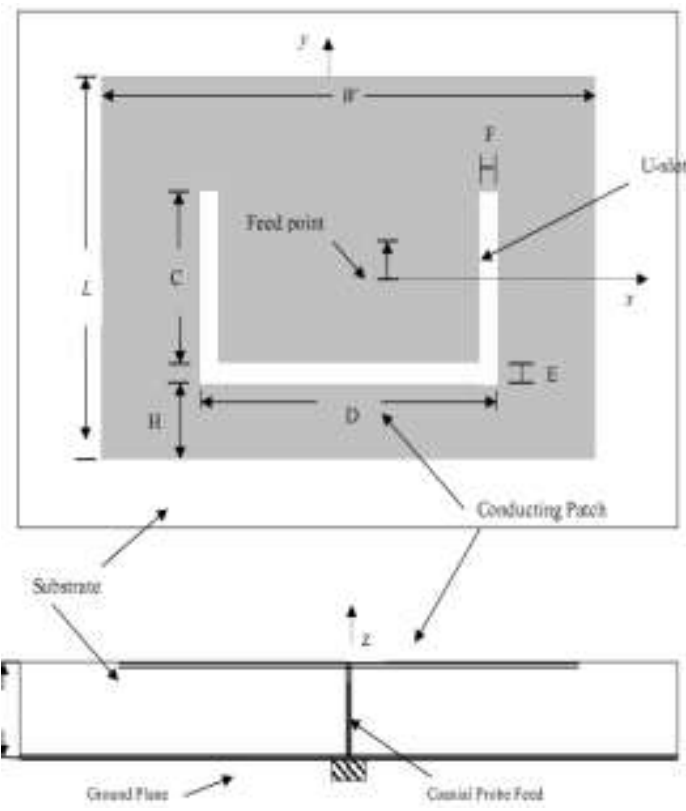

Figure -3 U Slotted Microstrip Antenna

\section{OPTIMISING PARAMETER:}

Using the optimization program, the user can set the lower bound and upper bound frequency to derive the bandwidth, while the dielectric constant is varied, Height $=35 \mathrm{~mm}$ of patch antenna. The optimized lower bound frequency, f low $=1 \mathrm{GHz}$, upper bound frequency, $\quad \mathrm{f}$ high $=1.5 \mathrm{GHz}$, Resonant Frequency $\mathrm{Fr}=1.25 \mathrm{Ghz}$, wire resistance $=50 \mathrm{ohm}$ is selected .after going through various substrate values using the optimization program the design parameters has derived and the bandwidth has been optimized.

When $\varepsilon r=2.2$, Height $=35 \mathrm{~mm}$, lower bound frequency, $\mathrm{f}$ low $=1 \mathrm{GHz}$, upper bound frequency, $\mathrm{f}$ high $=1.5 \mathrm{GHz}$, Resonant Frequency $\mathrm{Fr}=1.25 \mathrm{Ghz}$, wire resistance $=50 \mathrm{ohm}$ is selected for the parasitic patch and driven patch the computed results are shown in Table1 as:

Table 1

\begin{tabular}{|l|l|l|l|}
\hline \multicolumn{2}{|l|}{ Normal Patch Readings } & \multicolumn{2}{l|}{ U slot patch readings } \\
\hline Dielectric constant & 2.2 & Slot width & 52.023 \\
\hline Width & 94.46 & Slot height & 28.46 \\
\hline
\end{tabular}

\begin{tabular}{|l|l|l|l|}
\hline length & 55.08 & $\begin{array}{l}\text { Effective } \\
\text { dielectric constant }\end{array}$ & 1.7848 \\
\hline Input impedance & 151.30 & $\begin{array}{l}\text { Height of slot } \\
\text { from base }\end{array}$ & 12.05 \\
\hline $\begin{array}{l}\text { Effective patch } \\
\text { Dielectric constant }\end{array}$ & 1.857 & $\begin{array}{l}\text { Driven } \\
\text { length }\end{array}$ & Slot width E=F \\
\hline $\begin{array}{l}\text { Feed point } \\
\text { location }\end{array}$ & 16.804 & 4.06 \\
\hline Bandwidth(MHz) & 294.153 & Bandwidth $(\mathrm{MHz})$ & 618.68 \\
\hline
\end{tabular}

When $\varepsilon r=2.32$, Height $=35 \mathrm{~mm}$, lower bound frequency, f low $=1 \mathrm{GHz}$, upper bound frequency, $\mathrm{f}$ high $=1.5 \mathrm{GHz}$, Resonant Frequency $\mathrm{Fr}=1.25 \mathrm{Ghz}$, wire resistance $=50 \mathrm{ohm}$ is selected for the rectangular and $\mathrm{U}$ slot patch the computed results are shown below in table 2:

Table 2

\begin{tabular}{|l|l|l|l|}
\hline \multicolumn{2}{|l|}{ Normal Patch Readings } & \multicolumn{2}{|l|}{ U slot patch readings } \\
\hline Dielectric constant & 2.32 & Slot width & 51.06 \\
\hline Width & 93.138 & Slot height & 27.9414 \\
\hline length & 53.67 & $\begin{array}{l}\text { Effective } \\
\text { dielectric constant }\end{array}$ & 1.8612 \\
\hline Input impedance & 154.11 & $\begin{array}{l}\text { Height of slot } \\
\text { from base }\end{array}$ & 10.082 \\
\hline $\begin{array}{l}\text { Effective point } \\
\text { Dielectric constant }\end{array}$ & 1.9411 & $\begin{array}{l}\text { Parasitic patch } \\
\text { length }\end{array}$ & 25.060 \\
\hline $\begin{array}{l}\text { Feed } \\
\text { location }\end{array}$ & Slot width E=F & 4.0 \\
\hline Bandwidth(MHz) & 297.85 & Bandwidth(MHz) & 634.99 \\
\hline
\end{tabular}

When $\varepsilon r=2.6$, Height $=35 \mathrm{~mm}$, lower bound frequency, f low $=1 \mathrm{GHz}$, upper bound frequency, $\mathrm{f}$ high $=1.5 \mathrm{GHz}$, Resonant Frequency $\mathrm{Fr}=1.25 \mathrm{Ghz}$, wire resistance $=50 \mathrm{ohm}$ is selected for the rectangular and $U$ slot patch the computed results are shown in Table3 as:

Table 3

\begin{tabular}{|l|l|l|l|}
\hline \multicolumn{2}{|l|}{ Normal Patch Readings } & \multicolumn{2}{l|}{ U slot patch readings } \\
\hline Dielectric constant & 2.6 & Slot width & 49.06 \\
\hline Width & 89.44 & Slot height & 26.83 \\
\hline length & 50.68 & $\begin{array}{l}\text { Effective dielectric } \\
\text { constant }\end{array}$ & 2.0387 \\
\hline Input impedance & 160.48 & $\begin{array}{l}\text { Height of slot } \\
\text { from base }\end{array}$ & 6.14 \\
\hline $\begin{array}{l}\text { Effective patch } \\
\text { Dielectric constant }\end{array}$ & 2.135 & $\begin{array}{l}\text { Driven } \\
\text { length }\end{array}$ & Slot width E=F \\
\hline $\begin{array}{l}\text { Feed } \\
\text { location }\end{array}$ & 15.788 & 4.09 \\
\hline Bandwidth(MHz) & 301.96 & Bandwidth(MHz) & 665.06 \\
\hline
\end{tabular}

When $\varepsilon \mathrm{r}=3.0$, Height $=35 \mathrm{~mm}$, lower bound frequency, $\mathrm{f}$ low $=1 \mathrm{GHz}$, upper bound frequency, $\mathrm{f}$ high $=1.5 \mathrm{GHz}$, Resonant Frequency $\mathrm{Fr}=1.25 \mathrm{Ghz}$, wire resistance $=50 \mathrm{ohm}$ is selected for the rectangular and $U$ slot patch the computed results are shown as given below in Table 4

Table 4

Normal Patch Readings U slot patch readings 


\begin{tabular}{|l|l|l|l|}
\hline Dielectric constant & 3.0 & Slot width & 46.64 \\
\hline Width & 84.85 & Slot height & 25.45 \\
\hline length & 47.01 & $\begin{array}{l}\text { Effective } \\
\text { dielectric constant }\end{array}$ & 2.29 \\
\hline Input impedance & 169.16 & $\begin{array}{l}\text { Height of slot } \\
\text { from base }\end{array}$ & 1.74 \\
\hline $\begin{array}{l}\text { Effective patch } \\
\text { Dielectric constant }\end{array}$ & 2.40 & $\begin{array}{l}\text { Driven } \\
\text { length }\end{array}$ & 20.606 \\
\hline $\begin{array}{l}\text { Feed point } \\
\text { location }\end{array}$ & 14.90 & Slot width E=F & 4.0 \\
\hline Bandwidth(MHz) & 301.08 & Bandwidth(MHz) & 696.109 \\
\hline
\end{tabular}

\begin{tabular}{|c|c|c|c|}
\hline & & dielectric constant & \\
\hline Input impedance & 169.16 & $\begin{array}{l}\text { Height of slot } \\
\text { from base }\end{array}$ & 1.22 \\
\hline $\begin{array}{l}\text { Effective } \\
\text { Dielectric constant }\end{array}$ & 2.387 & $\begin{array}{l}\begin{array}{l}\text { Driven } \\
\text { length }\end{array} \\
\end{array}$ & 14.35 \\
\hline $\begin{array}{ll}\begin{array}{l}\text { Feed } \\
\text { location }\end{array} & \text { point } \\
\end{array}$ & 13.853 & Slot width E=F & 4 \\
\hline Bandwidth(MHz) & 371.24 & Bandwidth(MHz) & 1144.19 \\
\hline
\end{tabular}

\section{CONCLUSION}

Hence, it is proven by the results by changing the permittivity and introducing the slot (U) to the rectangular microstrip antenna, for the resonant frequency $1.25 \mathrm{MHz}$ material at the frequency range $1 \mathrm{GHz}$ to $1.5 \mathrm{GHz}$ and introducing the slots $\mathrm{U}$. The results are simulated with java optimization program. Stack

If we increase the height $=40 \mathrm{~mm}$ of the patch for $\varepsilon \mathrm{r}=3$ (mylar) the bandwidth can be increased up to $61 \%$. lower bound frequency, $\mathrm{f}$ low $=1 \mathrm{GHz}$, upper bound frequency, $\mathrm{f}$ high $=1.5 \mathrm{GHz}$, Resonant Frequency $\mathrm{Fr}=1.25 \mathrm{Ghz}$, wire resistance $=50 \mathrm{ohm}$ is selected for the rectangular and $U$ slot patch the computed results are shown in Table5 :

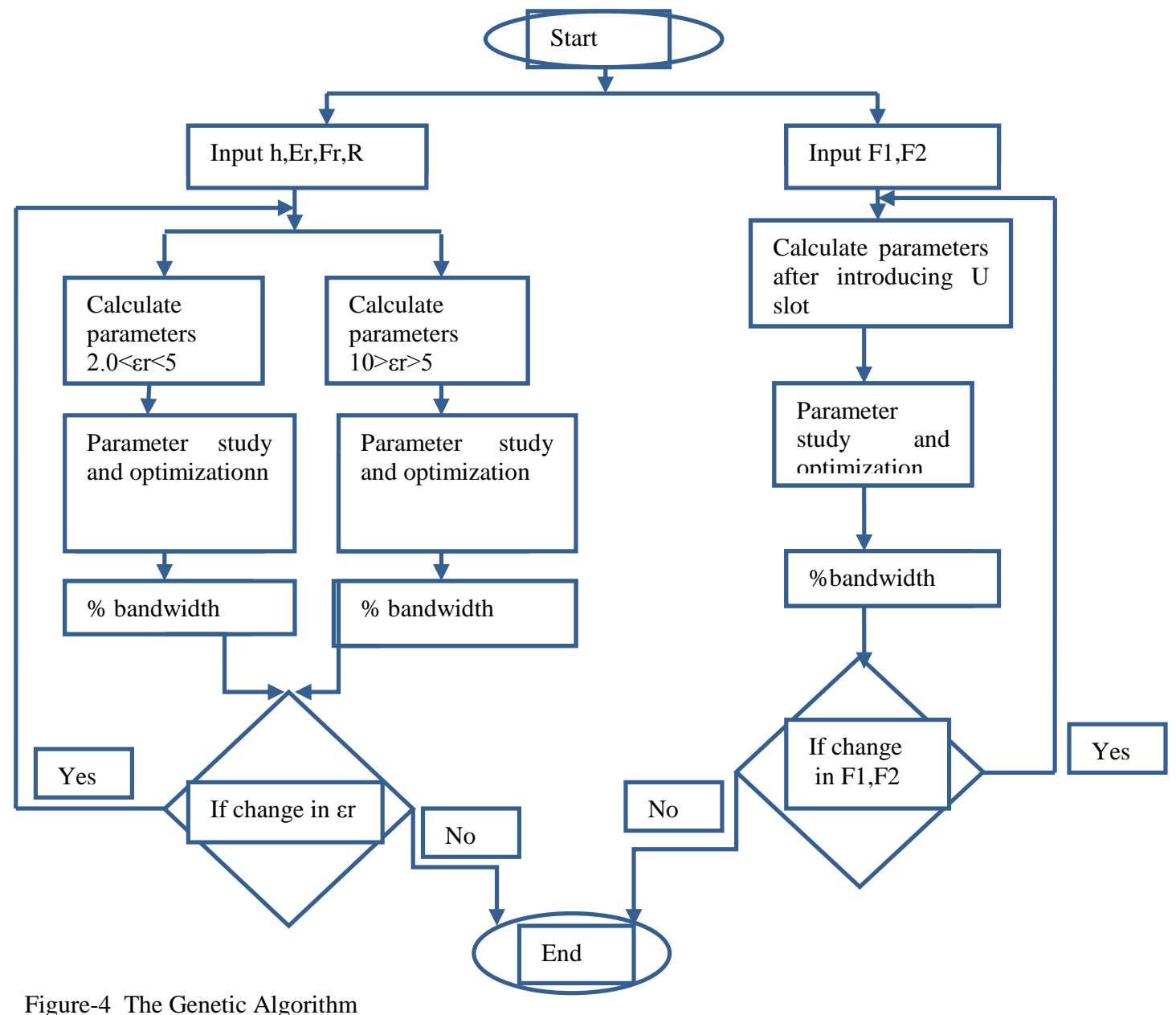

Table 5:

\begin{tabular}{|l|l|l|l|}
\hline \multicolumn{2}{|l|}{ Normal Patch Readings } & \multicolumn{2}{l|}{ U slot patch readings } \\
\hline Dielectric constant & 3.0 & Slot width & 46.83 \\
\hline Width & 84.85 & Slot height & 25.45 \\
\hline length & 43.696 & Effective & 2.27 \\
\hline
\end{tabular}

configuration with 2 patches, driven and parasitic, and the use of the various substrate loading technique increases the bandwidth of the antenna ranging from $23 \%-32 \%$. If we increase the height $(40 \mathrm{~mm})$ of the patch for $\varepsilon r=3$ (mylar) the bandwidth can be increased up to $61 \%$. 


\section{REFERENCES}

[1] John D. Kraus and Ronald J. Marhefka, "Antennas for All Applications, 3rdEdition”, McGraw-Hill, 2002.

[2] C. A Balanis, "Antenna Theory Analysis and Design, $2^{\text {nd }}$ Edition”, John Wiley \& Sons, New York, 1996.

[3] R. Garg, P. Bhartia, I. Bahl and A. Ittipiboon, "Microstrip Antenna Design Handbook", Artech House Antennas \& Propagation Library, (Nov 2000)

[4] T. Chakravarty, S. M. Roy, S. K. Sanyal and A. De, "A Nove Microstrip Patch Antenna with Large Impedance Bandwidth in VHF/UHF Range", Progress In Electromagnetics Research, PIER 54, 83-93, 2005

[5] D.M Pozar, "Microstrip Antennas", IEEE Proceedings, vol.80, pp.79-91 Jan1992

[6] S.V Khobragade (Lecturer, Dept of Electronics and Tele.) and Dr. S. N. Talbar (Prof and Head, Dept of Electronics and Telecomm.), "Bandwidth Enhancement and Comparison between Square Microstrip Patch Antenna", Dr. Babasaheb Ambedkar Technology University, Lonere

[7] Keith R. Carver, member, IEEE, and James W. Mink, member, IEEE "Microstrip Antenna Technology" IEEE Transactions on Antennas and Propagation, Vol. AP-29, No. 1, Jan 1981

[8] A. A. Abdelaziz "Bandwidth Enhancement of Microstrip Antenna" Progress In Electromagnetics Research, PIER 63, 311-317, 2006

[9] Martin Leong, Prof. Dr. Georg Splitt "Laboratory Manual: Microstrip Antenna Design using Mstrip40. Nov 2002

[10] Leo G. Maloratsky "Reviewing the Basics of Microstrip Lines" Microwaves \& RF March 2000

[11] Arun V Sathanur and K.J. Vinoy "A Two-Element Micromachined Microstrip Antenna Array with Improved Performance" Microwave Laboratory Department of Electrical Commuication Engineering Indian Institute of Science, Bangalore 560012 India.

[12] Gonca Cakir. Levent Sevgi "Design, Simulation and Tests of a Low-cost Microstrip Patch Antenna Arrays for the Wireless Communication" Turk J Elec Engin, Vol 13, No. 1 2005, (C) Tubitak.
[13] Naftali Herscovici, Manuel Fuentes Osorio and Custodio Peixeiro "Miniaturization of Rectangular Microstrip Patches Using Genetic Algorithms" IEEE Antennas and Wireless Propagation Letters, Vol. 1, 2002

[14] Yong-Woong Jang "Wide-Band T-Shaped Microstrip-Fed Twin-Slot Array Antenna" ETRI Journal, Volume 23, Number 1, March 2001

[15] Luis Jofre, Member, IEEE, Bedri A. Cetiner, Member, IEEE and Franco De Flaviis "Miniature Multi-Element Antenna for Wireless Communications" IEEE Transactions on Antennas and Propagation, Vol. 50, No. 5, May 2002

[16] J.-C. Langer, J. Zou, C. Liu, Senior Member, IEEE, and J.T. Bernhard, Senior Member, IEEE "Micromachined Reconfigurable Out-of-Plane Microstrip Patch Antenna Using Plastic Deformation Magnetic Actuation" IEEE Microwave and Wireless Components Letters, Vol. 13, No. 3, March 2003.

[17] Kamal Sarabandi, Fellow, IEEE, Amelia M. Buerkle, Student, Member, IEEE, and Hossein Mosallaei, Senior Member, IEEE "Compact Wideband UHF Patch Antenna on a Reactive Impedance Substrate” 0161-2006

[18] M Abbaspour,. and H.R. Hassani, wideband star shaped microstrip patch antenna , Progress in Electromagnetic Research Letters, 2008. Vol. 1, 61-68.

[19] Ansari, J.A., R.B. Ram, Broadband stacked U-slot microstrip patch antenna, Progress in Electromagnetic Research Letters 2008.,Vol. 4, 17-24,

[20] J.A Ansari, R.B. Ram and P. Singh, Analysis of a gapcoupled stacked annular ring microstrip antenna, Progress in Electromagnetic Research B, 2008, Vol. 4, 147-158.

[21] J.A Ansari, P. Singh, and N.P. Yadav, Analysis of shorting pin loaded half disk patch antenna for wideband operation, Progress in Electromagnetics Research C, 2009 Vol.6, 179. 192. 